\section{Research Article}

(c) 2021 Pratama et al. This is an open access article licensed under the Creative Commons Attribution-NonCommercial 4.o International License (https://creativecommons.org/licenses/by-nc/4.o/)

Received: 28 April 2021 / Accepted: 15 July 2021 / Published: 5 September 2021

\title{
Integrated Reporting in Southeast Asia: Does Value Creation Work?
}

\author{
Arie Pratama \\ Winwin Yadiati ${ }^{1}$ \\ Nanny Dewi Tanzil \\ Jadi Suprijadi ${ }^{2}$ \\ ${ }^{1}$ Department of Accounting, Faculty of Economics and Business, \\ Padjadjaran University, Kabupaten Sumedang, \\ Jawa Barat 45363, Indonesia \\ ${ }^{2}$ Department of Statistics, Faculty of Mathematics and Natural Science, \\ Padjadjaran University, Kabupaten Sumedang, \\ Jawa Barat 45363, Indonesia
}

DOI: https://doi.org/10.36941/ajis-2021-0123

\section{Abstract}

This study describes the factors affecting the quality of integrated reporting (IR) disclosure and how the disclosures affect firm value. This study employed quantitative methods with secondary data. This study sample includes 1,900 firms from 2016 to 2018. Descriptive statistics, cluster analysis, and structural equation modeling path analysis were used to describe the development. This study showed that the IR implementation in five countries currently has an adequate score. Hypothesis testing showed that three factors influenced the size of IR disclosures and the disclosures influence the firm value. This study implies that although IR in the current and future will be a role model for corporate reporting, Southeast Asian firms still need to strengthen the quality of IR. This study contributes to the current development and description of IR, which is limited because of its recent introduction, in five countries: Indonesia, Malaysia, Philippines, Singapore, and Thailand.

Keywords: integrated reporting, firm characteristics, corporate governance, media exposure, firm value

\section{Introduction}

Stakeholders acquire information through reporting. Historical reporting has several weaknesses, such as it still oriented toward historical data (Kulkarni, 2014; Pratama, 2018a); it is partial and only combines various nonfinancial information that does not explain the overall condition of the organization (Palenberg et al., 2006); and it does not explain the inputs and processes in the business and emphasizes more outputs and outcomes (Association of Chartered Certified Accountants (ACCA), 2012).

Studies on IR show that IR affects firm performance. Bernardi and Stark (2018) concluded that the implementation of IR in South Africa resulted in a strong disclosure relationship between 
environmental, social, and governance aspects and accurate financial performance forecasting. Before implementing IR, there was no strong correlation between these variables. A 2015 study by KPMG and the National University of Singapore showed that 80 firms in the Asia Pacific that implemented IR had a better risk-adjusted return than those that did not implement IR. Yeo et al. (2014) showed that a firm that widely discloses IR has a greater Tobin-Q value.

Wang (2017) explained that firm characteristics reflect the diversity of the firm's business activities, which may vary owing to differences in resources or current conditions in the firm. Studies have also shown that corporate governance (CG) factors can affect the extent of IR disclosures. Firms with good CG are more oriented to accountability and transparency of information; therefore, the information presented in the report becomes detailed and comprehensive (Forker, 1992; Haniffa and Cooke, 2002). Previous studies have shown CG on the structure or governance organ in the firm (Dodd and Warner, 1983; Hart, 1995; Adams et al., 2010). Studies have also stated that information media can determine the quality of disclosure. Lodhia (2004) stated that wider reporting media lead to demands for broader stakeholder transparency. Studies on the type of reporting media and its links to the extent of disclosure of the information are still limited, whereas IR is not only limited to hard copy media but can also be delivered through various media (Rivera-Arrublo and Zorio-Grima, 2016).

Research on the disclosure quality of IR items is still rarely found because IR has just been launched. Southeast Asia was chosen for this study because information disclosure practices and characteristics of the enterprise and governance structures are varied. This study analyzes the factors that influence the extent of disclosure of items in IR in the annual reports of firms in Southeast Asia. It also further links the extent of disclosure items in IR with firm value. In the following sections, Section 2 explains the relevant literature review, Section 3 describes the research methods used, Section 4 explains the results and discussions, and Section 5 presents the conclusion.

\section{Literature Review and Hypotheses Development}

\subsection{Firm Characteristics and IR}

Buitendag et al. (2017) explained that the quality of IR increases along with the increase in resources needed to prepare an integrated report. Girella et al. (2019) explained that IR is also part of the management strategy to report business as a whole, and considering that the characteristics of IR are still voluntary, various indicators of firm characteristics are needed to test its effect on the extent of disclosure.

This study uses firm characteristics variables from the framework proposed by Kogan and Tian (2012). Studies have included the variables of firm size, profitability, and leverage. This study adds the variables of firm age, ownership concentration, industry type, and auditor reputation. Large firms have complex activities, a greater impact on society, more shareholders, and receive additional attention from the public; therefore, large firms are under more pressure to express social responsibility. The firm's age shows how long the firm can last and it is generally interpreted as a manifestation of the theory of legitimacy. Ownership indicates the existing governance in a firm, the higher the concentration, the lower the quality of the disclosures. The firm's ability to generate profits attracts investors to invest their funds for business expansion; however, low profitability leads to investors withdrawing their funds. Leverage outlines the capital structure of the firm to show the level of uncollectible risk of debt. Scott (2009) explained that the higher the leverage the more likely the firm experiences a violation of the debt contract, then the manager reports higher current profits than future profits. Industries are divided into two types: high profile and low profile. Roberts (1992) described a high-profile industry as a firm that has a high level of sensitivity to the environment, political risk, or intense competition. DeAngelo (1981) stated that large-sized auditors have more incentives to avoid the criticism of reputation damage than small-sized auditors. The following hypothesis is proposed:

$\mathrm{H} 1$ : There is an influence of firm characteristics on the quality of IR. 


\section{$2.2 \quad C G$ and IR}

This study discusses the relationship between IR and CG by focusing on the firm's governance organs. CG is proxied by an independent commissioner, audit committee, gender diversity, and the number of board meetings. Adams (2015) explained that implementing integrated thinking depends on the readiness of various organs in the firm. The activities of the governance organs are also important because implementing IR requires a mature action plan and detailed supervision from the firm's management (Maroun, 2018).

Frías-Aceituno et al. (2013) explained that the board of commissioners assumes a supervisory function to ensure that IR contains all essential information about creating corporate value. Makiwane and Padia (2013) explained that the independence of the board of directors is key to implementing IR because independence can prevent biased information about the firm and increase firm transparency. Adhariani and de Villiers (2019) explained that as an organ of the board of commissioners, the audit committee strengthened the quality of IR because the audit committee was specialized in accounting and reporting, which was the key to IR information. Srinidhi et al. (2011) stated that women directors have higher social traits and feelings, making it easier to adopt social and environmental reporting needs in IR. García-Sánchez and Noguera-Gámez (2018) explained that the more complex activities of the board of directors in undertaking planning, implementation, and supervision affect better governance and business management that would improve the quality of IR. The following hypothesis was proposed:

H2: There is an influence of CG on the quality of IR.

\subsection{Media Exposure and IR}

Picard (2005) explained that the development of publication media is a convergence of the information demanded by stakeholders with that offered in the form of media publications (supply of corporations). This diverse information media has created a market for digital media, which is the current trend in media reporting. Hodinka et al. (2012) explained that publication media have different approaches at different times. Reports in publication media historically were in the form of oral media. The media for writing publications also developed from handwritten media, typed, to be published via the internet (internet reporting). Siew (2015) explained that reporting media is a tool that has a framework, standards, and regulations, which create standardized information. Uyar (2016) explained that corporate reporting has changed in various aspects, including (1) the contents of the report, (2) reporting media, (3) target audience, (4) type of report, and (5) reporting design. The following hypothesis was proposed:

$\mathrm{H}_{3}$ : There is an influence of media exposure on the quality of IR.

\subsection{Firm Value and IR}

Healy and Palepu (2001) stated that if the information conveyed is transparent and truthful, then the firm's value, which is proxied through the stock market price, will be precise. Popova et al. (2013) showed that firms that disclose information under legal provisions are considered to meet legal requirements and are a low risk so that the firm value increases from the investors' perspectives. Iatridis (2013) also stated that if the disclosures in the report are good, investors have a clear perception of the firm's operations, which increases the relevance of the firm's value. The following hypothesis was proposed:

$\mathrm{H}_{4}$ : There is an influence of IR quality on firm value.

\section{Methodology}

The study population includes all issuers that publish annual reports and listed on five stock exchanges: Indonesia, Malaysia, Singapore, Thailand, and the Philippines. The study considered 2016-2018 as the 
sample period. The study population included 1,90o firms or 5,700 observations over 3 years.

The operationalization of variables can be stated in the following matrix (Table I).

Table 1: Operationalization of Variables

\begin{tabular}{|c|c|}
\hline VARIABLE & FORMULA \\
\hline Firm Size $\left(\mathrm{X}_{1}\right)$ & LN Total Asset \\
\hline Financial Leverage $\left(\mathrm{X}_{2}\right)$ & (Total Debt/Total Capital) \\
\hline Ownership Concentration $\left(\mathrm{X}_{3}\right)$ & $\begin{array}{l}\text { (Total outstanding shares are owned by ultimate shareholders/total } \\
\text { outstanding shares) }\end{array}$ \\
\hline Firm Age $\left(\mathrm{X}_{4}\right)$ & The age of the firm since it was founded \\
\hline Profitability $\left(\mathrm{X}_{5}\right)$ & Net income/Total Asset \\
\hline Industry type $\left(\mathrm{X}_{6}\right)$ & $\begin{array}{l}4=\text { environment based manufacturing firms } \\
3=\text { environment based non-manufacturing firms } \\
2 \text { = non-environment based manufacturing firms } \\
1=\text { non-environment based non-manufacturing firms }\end{array}$ \\
\hline Size of the Public Accounting Firm $\left(\mathrm{X}_{7}\right)$ & $\begin{array}{l}3=\text { if audited by a Big } 4 \text { affiliated public accounting firm } \\
2=\text { if audited by a non-big } 4 \text { foreign-affiliated public accounting firm } \\
1=\text { if audited by a not foreign-affiliated public accounting firm }\end{array}$ \\
\hline $\begin{array}{l}\text { Composition of Independent } \\
\text { Commissioners }\left(\mathrm{X}_{8}\right)\end{array}$ & (Total independent commissioners / Total commissioners) \\
\hline Audit Committee Composition $\left(\mathrm{X}_{9}\right)$ & $\begin{array}{l}\text { (Total audit committee with accounting background / Total of audit } \\
\text { committees) }\end{array}$ \\
\hline Gender on the Board of Directors $\left(\mathrm{X}_{10}\right)$ & (Total female directors / Total directors) \\
\hline $\begin{array}{l}\text { Number of Board of Directors Meetings } \\
\left(\mathrm{X}_{\mathrm{n}}\right)\end{array}$ & Number of board meetings in one year \\
\hline Media Exposure $\left(\mathrm{X}_{12}\right)$ & Number of media publications on annual reports \\
\hline Disclosure of IR Items (Y) & Use the IR matrix as disclosed in Pratama et al. (2019) \\
\hline The value of the firm $(\mathrm{Z})$ & Share price / Book value of the share \\
\hline
\end{tabular}

The value of the firm's IR quality is compared by country and type of industry, and clusterized using cluster analysis. The path analysis approach is used to test the research hypotheses. The path analysis model can be provided as follows: $Z=P_{Z Y} Y+\varepsilon(1) ; Y=P_{Y X_{1}} X_{1}+P_{Y X_{2}} X_{2}+P_{Y X_{3}} X_{3}+P_{Y X_{4}} X_{4}+P_{Y X_{5}} X_{5}+$ $P_{Y X 6} X_{6}+P_{Y X_{7}} X_{7}+P_{Y X 8} X_{8}+P_{Y X_{9}} X_{9}+P_{Y X_{10}} X_{10}+P_{Y X_{11}} X_{11}+P_{Y X_{12}} X_{12}+P_{Y X_{13}} X_{13}+\varepsilon$ (2)

\section{Results and Discussion}

\subsection{Results}

Table II describes research variables in general, and Table III explains the disclosure quality score of IR items by industry type.

Table 2: Description of Research Variables

\begin{tabular}{|l|c|c|c|c|c|c|c|c|c|c|c|c|c|c|}
\hline Description & $\mathrm{X}_{1}$ & $\mathrm{X}_{2}$ & $\mathrm{X}_{3}$ & $\mathrm{X}_{4}$ & $\mathrm{X}_{5}$ & $\mathrm{X} 6$ & $\mathrm{X}_{7}$ & $\mathrm{X} 8$ & $\mathrm{X}_{9}$ & $\mathrm{X}_{10}$ & $\mathrm{X}_{11}$ & $\mathrm{X}_{12}$ & $\mathrm{Y}$ & $\mathrm{Z}$ \\
\hline Average & 19.61 & 1.42 & 0.39 & 33.92 & 0.00 & 1.98 & 2.76 & 0.51 & 0.57 & 0.15 & 6.43 & 1.72 & 104.87 & 1.34 \\
\hline Std. Deviation & 2.76 & 7.80 & 0.21 & 21.94 & 0.03 & 0.91 & 0.88 & 0.20 & 0.38 & 0.19 & 5.67 & 0.45 & 20.80 & 1.44 \\
\hline
\end{tabular}

Table 3: IR Score as Per Industry Type

\begin{tabular}{|c|c|c|c|c|c|c|c|c|c|c|}
\hline Description & Agriculture & Mining & $\begin{array}{c}\text { Basic } \\
\text { Industry }\end{array}$ & $\begin{array}{c}\text { Miscellaneous } \\
\text { Industry }\end{array}$ & $\begin{array}{c}\text { Consumer } \\
\text { Goods Industry }\end{array}$ & Infrastructure & Property & Finance & $\begin{array}{l}\text { Trade and } \\
\text { Service }\end{array}$ & Total \\
\hline Average & 116.13 & 103.46 & 98.96 & 99.68 & 103.59 & 107.69 & 107.64 & 109.51 & 103 & 104.87 \\
\hline $\begin{array}{c}\text { Standard } \\
\text { Deviation }\end{array}$ & 21.52 & 22.72 & 19.92 & 17.73 & 18.41 & 20.07 & 21.17 & 23.92 & 18.70 & 20.58 \\
\hline
\end{tabular}


Per Table III, the average score on the disclosure of IR items is 104.87 or $67.22 \%$, which is still low. If we assess nine industries, only four industries have disclosure scores above the average, namely, agriculture, infrastructure, property, and finance.

Table IV illustrates the results for each IR component score.

Table 4: IR Component Score

\begin{tabular}{|l|c|c|c|c|c|c|c|c|}
\hline Description & Org_Ovw & Gov & Bus_Mod & Risk_Op & Strat\&RA & Performance & Outlook & Basis \\
\hline Average & 21.99 & 17.76 & 19.02 & 4.85 & 10.36 & 10.12 & 7.89 & 12.87 \\
\hline Standard Deviation & 4.50 & 4.39 & 4.81 & 1.28 & 2.25 & 2.19 & 1.84 & 3.35 \\
\hline Percentage & $68.73 \%$ & $63.44 \%$ & $67.91 \%$ & $60.62 \%$ & $64.75 \%$ & $63.28 \%$ & $65.76 \%$ & $80.47 \%$ \\
\hline
\end{tabular}

Table IV shows that the average score of disclosure per component is still approximately $60 \%$, except for the basis for the presentation of $80 \%$.

Table $\mathrm{V}$ presents the disclosure score of each integrated report disclosure item by country.

Table 5: IR scores as per country

\begin{tabular}{|l|c|c|c|c|c|c|}
\hline Description & Indonesia & Malaysia & Philippine & Singapore & Thailand & Total \\
\hline Average & 102.15 & 114.97 & 81.90 & 97.35 & 97.99 & 104.87 \\
\hline Standard Deviation & 20.84 & 18.56 & 11.24 & 19.69 & 8.79 & 20.58 \\
\hline Percentage & $65.48 \%$ & $73.70 \%$ & $52.50 \%$ & $62.40 \%$ & $62.81 \%$ & $67.23 \%$ \\
\hline
\end{tabular}

Table V shows that only Malaysia has an IR disclosure score exceeding the average. The Philippines has the lowest IR disclosure score.

\subsection{Cluster Analysis}

The following is a description of the average value of the cluster (Table VI)

Table 6: General Cluster Description

\begin{tabular}{|l|c|c|c|c|c|c|}
\hline Description & Cluster 1 & Cluster 2 & Cluster 3 & Cluster 4 & Cluster 5 & Cluster 6 \\
\hline Org_Ovw & 28.77 & 24.47 & 22.65 & $\mathbf{2 0 . 2 2}$ & 16.97 & 13.42 \\
\hline Gov & 24.99 & 20.44 & 17.7 & 15.74 & 13.24 & 9.75 \\
\hline Bus_Mod & 25.73 & 23.03 & 16.29 & 19.24 & 13.75 & 10.76 \\
\hline Risk_Op & 6.86 & 5.14 & 4.92 & 4.23 & 3.95 & 3.14 \\
\hline Strat\&RA & 13.87 & 10.83 & 10.68 & 9.52 & 8.32 & 7.1 \\
\hline Performance & 13.85 & 10.78 & 10.09 & 9.1 & 8.33 & 7.2 \\
\hline Outlook & 10.33 & 8.86 & 7.37 & 7.95 & 6.05 & 4.61 \\
\hline Basis & 15.02 & 14.91 & 9.36 & 15.67 & 10.35 & 8.58 \\
\hline
\end{tabular}

The data were described for each type of industry and each country of the research subject. Tables VII and VIII present descriptions as follows:

Table 7: Number of General Cluster Firms per Country

\begin{tabular}{|l|c|c|c|c|c|c|}
\hline Description & Cluster 1 & Cluster 2 & Cluster 3 & Cluster 4 & Cluster 5 & Cluster 6 \\
\hline Indonesia & 78 & 67 & 170 & 8 & 89 & 31 \\
\hline Malaysia & 172 & 256 & 8 & 307 & 41 & 7 \\
\hline Philippine & 0 & 0 & 38 & 0 & 78 & 7 \\
\hline Singapore & 27 & 46 & 14 & 127 & 97 & 28 \\
\hline Thailand & 0 & 2 & 180 & 0 & 19 & 3 \\
\hline Total & 277 & 371 & 410 & 442 & 324 & 76 \\
\hline
\end{tabular}


Table 8: General Cluster Members by Industry Type

\begin{tabular}{|l|c|c|c|c|c|c|}
\hline Description & Cluster 1 & Cluster 2 & Cluster 3 & Cluster 4 & Cluster 5 & Cluster 6 \\
\hline Agriculture & $\mathbf{3 0}$ & $\mathbf{2 4}$ & $\mathbf{4}$ & $\mathbf{2 3}$ & $\mathbf{1 1}$ & $\mathbf{1}$ \\
\hline Mining & $\mathbf{1 9}$ & $\mathbf{2 6}$ & $\mathbf{2 7}$ & $\mathbf{1 2}$ & $\mathbf{2 8}$ & 5 \\
\hline Basic Industry & $\mathbf{1 8}$ & $\mathbf{2 7}$ & 55 & 48 & 49 & 11 \\
\hline Miscellaneous Industry & 15 & 41 & 49 & 91 & 55 & 15 \\
\hline Consumer Goods Industry & 14 & 24 & 34 & 38 & 21 & 4 \\
\hline Property & 56 & 83 & 46 & 89 & 48 & 11 \\
\hline Infrastructure & 36 & 53 & 47 & 39 & 27 & 11 \\
\hline Finance & 51 & 16 & 69 & 15 & 25 & 5 \\
\hline Trade and Service & 38 & 77 & 79 & 87 & 60 & 13 \\
\hline Total & 277 & 371 & 410 & 442 & 324 & 76 \\
\hline
\end{tabular}

The tables show that profiling can be made from each cluster as follows.

1. Cluster 1 is one with the highest average score of eight components compared with other clusters. Firms from Malaysia dominated Cluster 1. In terms of the type of industry, financial industry, infrastructure, and property are the three biggest industries that have the highest number of members in Cluster 1.

2. Cluster 2 consists of the second-highest average component score after Cluster 1 . Characteristics per country of Cluster 2 are similar to that of Cluster 1, Regarding the type of industry, Cluster 2 is dominated by firms from the infrastructure, trade and services, and property industry.

3. The third is a cluster with the third-highest average component score among the clusters. However, when viewed in detail, Cluster 3 has a lower level of disclosure in the Business Model, Outlook, and Basis for Presentation components compared with Cluster 4.

4. Cluster 4 has the fourth-highest average component score and the highest number of members, that is, 442 firms.

5. Cluster 5 has the fifth-highest average component score overall. Firms from Singapore and the Philippines dominate this cluster. Firms from the trade and service, basic, and miscellaneous industries dominate the number of members in this cluster.

6. Cluster 6 is the lowest score among the other clusters. In terms of the type of industry, the number of members of the nine industries is fairly evenly distributed.

Based on the Cluster profiling above, it can be said that the six Clusters can be identified as follows:

1. First Cluster: Excellent IR Quality

2. Second Cluster: Good IR Quality

3. Third Cluster: Adequately IR Quality

4. Fourth Cluster: Fair IR Quality

5. Fifth Cluster: Marginal IR Quality

6. Sixth Cluster: Poor IR Quality

\subsection{Path Analysis}

The goodness of fit test showed that the model is fit to be interpreted. Table IX shows that only leverage, gender diversity, and media exposure have a different coefficient sign. All the hypotheses were accepted. 
Table 9: Path Analysis Result

\begin{tabular}{|c|c|c|}
\hline Path Coefficient & Standardized Estimates & Expected Sign \\
\hline $\mathrm{P}_{\mathrm{YX}_{1}}$ & 0.1288 & + \\
\hline $\mathrm{P}_{\mathrm{YX}_{2}}$ & -0.0011 & $+/-$ \\
\hline $\mathrm{P}_{\mathrm{YX}_{3}}$ & -0.1340 & - \\
\hline $\mathrm{P}_{\mathrm{YX}_{4}}$ & 0.0789 & + \\
\hline $\mathrm{P}_{\mathrm{YX}_{5}}$ & 0.0212 & + \\
\hline $\mathrm{P}_{\mathrm{YX} 6}$ & -0.0318 & $+/-$ \\
\hline $\mathrm{P}_{\mathrm{YX}}$ & 0.1841 & + \\
\hline $\mathrm{P}_{\mathrm{YX} 8}$ & 0.2776 & + \\
\hline $\mathrm{P}_{\mathrm{YX} 9}$ & 0.1179 & + \\
\hline $\mathrm{P}_{\mathrm{YX}_{10}}$ & -0.0170 & + \\
\hline $\mathrm{P}_{\mathrm{YX} 11}$ & 0.1334 & + \\
\hline $\mathrm{P}_{\mathrm{YX}_{12}}$ & -0.0182 & $+/-$ \\
\hline $\mathrm{P}_{\mathrm{ZY}}$ & 0.0431 & $+/-$ \\
\hline
\end{tabular}

\subsection{Discussion}

The results showed a positive influence of firm size on the extent of disclosure of IR items. The firm eventually makes more disclosures to satisfy stakeholders' demands. Various studies on the implementation of IR show that large firms can better implement IR because all levels of the organization understand how their firms create value (Buitendag et al. 2017; Dilling and Caykoylu, 2019) and can afford the high reporting costs (Steyn, 2014; Haji and Hossain, 2016).

The results showed that financial leverage negatively affected the coverage of IR items. Studies have focused on the political cost theory, where large debts lead to higher political costs for a firm, which in turn results in firms disclosing information extensively (Benyasrisawat and Basiruddin, 2012; Alzoubi, 2017).

The results showed that widespread ownership increases the extent of disclosure of IR items. Regarding its implications for IR, concentrated ownership leads to fewer needs for information conveyed by IR (Hope et al. 2011). Majority shareholders who have concentrated ownership are not broad-minded and tend to be secretive regarding the firm's processes, especially regarding the business environment, strategy, and the risks or opportunities that exist in the organization, because (1) strategy and business can be emulated by competing firms (Chernykh, 2008); (2) capital loss because it reveals the risks or negative impacts that exist in the firm (Grosman, 2016).

The results showed that older firms demonstrated wider disclosure of IR items. The firm can survive because it has a long-lasting value-creation process (Busco et al., 2013). A bankrupt firm fails to develop and execute a strategy and does not earn trust from the stakeholders (Beattie and Smith, 2013). Mature firms have the prerequisites to promptly respond to the stakeholders' changing needs, such as reporting the value-creation process through IR (Dumay et al., 2017; Feng et al., 2017).

The results showed that the higher the profitability of the firm, the wider the disclosure of IR. Investors perceive that the information generated must be positive, and they tend to panic when negative information is received (Trang and Phuong, 2015). Another perspective is related to the firm's focus, loss-making firms focus on improving their strategy and operations and ignoring administrative aspects, such as reporting (Hahn and Lülfs, 2019). IR is still voluntary reporting that may be ignored by poorly performing firms (Haji and Hossain, 2016).

The results showed that the type of industry affects extensive disclosure; specifically, nonenvironment-based and non-manufacturing firms have more extensive IR disclosure. Various reasons lead to this difference. First, the emergence of the concept of sustainability not just in extractive sectors but also in other sectors as well, such as banking and finance (Jeucken, 2004; Sobhani et al., 2012). Second, South East Asia is mostly dominated by non-manufacturing sectors, namely, industries 
such as infrastructure, trade, services, and property industries are growing rapidly (Schwab, 2017; Li and Hall, 2020).

The results showed that firms audited by the Big 4 public accounting firms have an extensive IR disclosure item. In addition to performance, information such as risk and opportunity, as well as the basis for presentations, is also related to the scope of the work by public accounting firms (Abeysekera, 2013). Foreign-affiliated public accounting firms have a wider international network, which allows access to more literature, personnel, and audit techniques (Lawrence et al., 2011). Public firms are highly complex and can be audited appropriately if public accounting firms have good resources (Keskinen et al., 2003; Campa, 2013; Pratama, 2018b).

The results showed that the extent of IR disclosure items can be increased by having more independent directors on board. Independence guarantees that the firm has adopted good business practices and not pervaded by the owners' vested interests (Knyazeva et al., 2013; Masulis and Mobbs, 2013). In addition to awareness, independent supervision ensures that the firm discloses all components in IR without choosing information that only has a positive impact (Stent and Dowler, 2015).

The results showed that the more members of the audit committee with accounting background results in more extensive disclosure of IR items. Accounting teaches business analysis, economics, and comprehensive reporting, which is the basis for understanding the IR concepts (Lary and Taylor, 2012; Ghafran and O'Sullivan, 2013; Arismajayanti and Jati, 2017).

Women directors reduce the extent of IR disclosures. These results contradict studies that state that the composition of female directors increases the extent of disclosure. In the five research subject countries, the board of directors was still dominated by men. Southeast Asian countries still have a large gender gap (Chang and England, 2011) and suffer much stigma in terms of tradition, religion, or culture that place women in non-leader gender roles (Setyonaluri, 2014; Qian and Sayer, 2016).

The results showed that the IR disclosure items would increase if more directors' meetings were held. The directors' meeting indicates a discussion of problems and their solutions (Johl et al., 2015; Eluyela et al., 2018). Directors engaging in several meetings have more robust business processes understanding (Vafeas, 1999), which in turn help in IR to convey information about the firm.

The results showed that a lower number of media publications lead to a reduction in the quality of IR disclosure. In this study, data obtained showed that the five research subject countries had only two maximum reporting media, namely, hard copy and internet. A lower number of items were disclosed, and the data only presented a summary of the performance.

The results showed that the extent of IR disclosure items had a positive effect on firm value. Firms have not only financial value, but also social, intellectual, and manufacturing values (IIRC, 2013; Pratama et al., 2019). Investors have now begun to shift from the financial paradigm, from short-term information to integrated, all-time sphere information (Dumay et al., 2017).

\section{Conclusions}

To conclude, first, the discussion related to firm characteristics is based on the political cost theory. Political cost theory explains that to reduce political costs, firms should disclose better information and satisfy stakeholder demands. Therefore, firms with certain characteristics will continue to adopt various forms of corporate reporting in the future to satisfy the stakeholders' interests. Second, in the discussion related to CG factors, supervisory and executive functions within the firm are important for increasing the extent of disclosure of IR items. The supervisory and execution functions must have sufficient composition in terms of quantity and quality. Third, although the IR disclosure items increase the firm value, its implementation is still in the awareness stage and the momentum should be maintained in the future, so the IR disclosure items have a greater effect on firm value. Fourth, the disclosure of IR items largely falls under the category of "adequately good." There is still a need for the great effort in the future to increase the quality of the IR. 
Suggestions can be made to several parties. IR can be adopted as a form of reporting in public firms to increase firm value and information transparency. Regulators should consider communicating the importance of IR because the new IR framework should be understood by all stakeholders and the firm. Firms can consider infrastructure and procurement plans to implement better IR. For professional associations and educational institutions, it is necessary to socialize the concept of IR and assists in implementing it through education. Future researchers can analyze the reporting infrastructure needed for implementing IR, and the cost-benefit analysis related to compliance costs and the benefits of reporting by cross-comparison between countries if the five subject countries firms have fully implemented IR in the future.

\section{References}

Abeysekera, I. (2013), “A template for integrated reporting”, Journal of Intellectual Capital, Vol. 14 No. 2, pp.227245.

Association of Chartered Certified Accountants (ACCA) (2012), "Accountancy futures: Re-assessing value of corporate reporting", available at: https://www.accaglobal.com/content/dam/acca/global/PDFtechnical/financial-reporting/reassessing-value.pdf (accessed 13 August 2018).

Adams, R.B., Hermalin, B.E. and Weisbach, M.S. (2010), "The role of boards of directors in corporate governance: A conceptual framework and survey", Journal of Economic Literature, Vol. 48 No. 1, pp.58-107.

Adams, C.A. (2015), "The International Integrated Reporting Council: A call to action", Critical Perspective on Accounting, Vol. 27, pp.23-28.

Adhariani, D. and de Villiers, C. (2019), "Integrated reporting: perspectives of corporate report preparers and other stakeholders", Sustainability Accounting, Management, and Policy Journal, Vol. 1o No. 1, pp.126-156.

Alzoubi, E.S.S. (2017), "Audit quality, debt financing, and earnings management: evidence from Jordan", Journal of International Accounting, Auditing, and Taxation, Vol. 11 No. 1, pp.51-76.

Arismajayanti, N.P.A. and Jati, K.I. (2017), "Influence of Audit Committee Competence, Audit Committee Independence, Independent Commissioner and Leverage on Tax Aggressiveness", Journal of Auditing, Finance, and Forensic Accounting, Vol. 5 No. 2, pp.109-119.

Beattie, V. and Smith, S.J. (2013), "Value creation and business models: refocusing the intellectual capital debate", British Accounting Review, Vol. 45 No. 4, pp.243-254.

Benyasrisawat, P. and Basiruddin, R. (2012), "Debt, equity, and dividend", Executive Journal, pp.61-69.

Bernardi, C. and Stark, A.W. (2018), "Environmental, social, and governance disclosure, integrated reporting, and the accuracy of analyst forecasts", British Accounting Review, Vol. 50 No. 1, pp.16-31.

Buitendag, N., Fortuin, G.S., and de Laan, A. (2017), "Firm characteristics and excellence in integrated reporting", South African Journal of Economic and Management Sciences, Vol. 20 No. 1, pp.1-8.

Busco, C., Frigo, M.L., Quattrone, P. and Riccaboni, A. (2013), "Redefining corporate accountability through integrated reporting", Strategic Finance, Vol. 8, August, pp.33-41.

Chang, C.F. and England, P. (2011), "Gender inequality in earnings in industrialized East Asia", Social Science Research, Vol. 40 No. 1, pp.1-14.

Chernykh, L. (2008), "Ultimate ownership and control in Russia", Journal of Financial Economics, Vol. 88 No. 1, pp.169-192.

DeAngelo, L.E. (1981), "Auditor size and audit quality", Journal of Accounting and Economics, Vol. 3 No. 3, pp.183199.

Dilling, P.F.A. and Caykoylu, S. (2019), "Determinants of companies that disclose high-quality integrated reports", Sustainability, Vol. 11 No. 13, p.3744.

Dodd, P. and Warner, J.B. (1983), "On corporate governance: A study of proxy contests", Journal of Financial Economics, Vol. 11 No. 1-4, pp.401-438.

Campa, D. (2013), “Big 4 fee premium' and audit quality: latest evidence from the UK listed firms" Managerial Auditing Journal, Vol. 28 No. 8, pp.680-707.

Dumay, J., Guthrie, J., and La Torre, M. (2017), "Barriers to implementing the international integrated reporting framework: A contemporary academic perspective", Meditari Accountancy Research, Vol. 25 No. 4, pp.461480.

Eluyela, D.F., Akintimehin, O.O., Okere, W, Ozordi, E., Osuma, G.O., Ilogho, S.O. and Oladipo, O.A. (2018), "Board meeting frequency and firm performance: Examining the nexus in Nigerian deposit money banks", Heliyon, Vol. 4 No. 10, eoo85o. 
Feng, T., Cummings, L. and Tweedie, D. (2017), "Exploring integrated thinking in integrated reporting - an exploratory study in Australia", Journal of Intellectual Capital, Vol. 18 No. 2, pp.330-353.

Forker, J.J. (1992), “Corporate governance and disclosure quality”, Accounting and Business Research, Vol. 22 No. 86, pp.111-124.

Frías-Aceituno, J.V., Rodríguez-Ariza, L. and García-Sánchez, I.M. (2013), "The role of the board in the dissemination of integrated corporate social reporting”, Corporate Social Responsibility and Environmental Management, Vol. 20 No. 4, pp.219-233.

García-Sánchez, I.-M. and Noguera-Gámez, L. (2018), "Institutional investor protection pressures versus firm incentives in the disclosure of integrated reporting”, Australian Accounting Review, Vol. 28 No. 2, pp.199219.

Ghafran, C. and O'Sullivan, N. (2013), "The governance role of audit committees", International Journal of Management Reviews, Vol. 15, pp.381-407.

Girella, L., Rossi, P. and Zambon, S. (2019), "Exploring the firm and country determinants of the voluntary adoption of integrated reporting”, Business Strategy and the Environment, Vol. 28 No. 7, pp.1323-1340.

Grosman, A., Okhmatovskiy, I. and Wright, M. (2016), "State control and corporate governance in transition economies: 25 years on from 1989", Corporate Governance: an International Review, Vol. 24 No. 3, pp.200-221.

Hahn, R. and Lülfs, R. (2019), "Legitimizing negative aspects of GRI-oriented sustainability reporting: a qualitative analysis of corporate disclosure strategies", Journal of Business Ethics, Vol. 123 No. 3, pp.401-420.

Haji, A.A. and Hossain, D.M. (2016), "Exploring the implications of integrated reporting on organisational reporting practice: evidence from highly regarded integrated reporters", Qualitative Research in Accounting and Management, Vol. 13 No. 4, pp.415-444.

Haniffa, R. and Cooke, T. E. (2002), “Culture, Corporate Governance, and Disclosure in Malaysian Corporations”, Abacus, Vol. 38 No. 3, pp.317-349.

Hart, O. (1995), “Corporate governance: some theory and implications”, Economic Journal, Vol. 105 No. 430, pp.678-689.

Healy, P.M., and Palepu, K.G. (2001), "Information asymmetry, corporate disclosure, and the capital markets: a review of the empirical disclosure literature", Journal of Accounting and Economics, Vol. 31 No. 1-3, pp.405440.

Hodinka, M., Štencl, M., Hřebíček, J. and Trenz, O. (2012), “Current trends of corporate performance reporting tools and methodology design of multifactor measurement of firm overall performance", Acta Universitatis Agriculturae et Silviculturae Mendelianae Brunensis, Vol. 6o, pp.85-9o.

Hope, O.-K., Thomas, W.B. and Vyas, D. (2011), "Financial credibility, ownership, and financing constraints in private firms”, Journal of International Business Studies, Vol. 42 No. 7, pp.935-957.

International Integrated Reporting Committee (IIRC) (2013) The International <IR> Framework, IIRC, London, available at: https://integratedreporting.org/resource/international-ir-framework/

Iatridis, G.E. (2013), "Environmental disclosure quality: evidence on environmental performance, corporate governance and value relevance", Emerging Markets Review, Vol. 14, pp.55-75.

Jeucken, M. (2004), Sustainability in Finance: Banking on the Planet, Eburon Academic Publishers, Netherlands.

Johl, S.K., Kaur, S. and Cooper, B.J. (2015), "Board characteristics and firm performance: evidence from Malaysian public listed firms", Journal of Economics, Business, and Management, Vol. 3 No. 2, pp.239-243Kawai, M., Hahm, H. and Iarossi, G., 2003. Corporate Foreign debt in East Asia: too much or too little?", Asian Corporate Recovery: Findings from Firm-Level Surveys in Five Countries, pp.111-121.

Keskinen, A., Aaltonen, M. and Kelly, E.M. (2003), Organisational Complexity, FFRC Publication Series (1/2003). TUTU Publications, Helsinki, Finland.

Knyazeva, A., Knyazeva, D. and Masulis, R.W. (2013), “The supply of corporate directors and board independence”, Review of Financial Studies, Vol. 26 No. 6, pp.1561-1605.

Kogan, L. and Tian, M. (2012), "Firm characteristics and empirical factor models: A data-mining experiment". International Finance, Discussion Papers Number 1070, Federal Reserve, New York System.

KPMG and National University of Singapore (NUS) (2015), “Toward Better Business Reporting”, available at: https://www.researchgate.net/publication/307890433_Towards_better_business_reporting (accessed 10 February 2017).

Kulkarni, A.R. (2014), “A review of concept and reporting of non-financial initiatives of business organisations", Procedia Economics and Finance, Vol. 11, pp. 33-41.

Lary, A.M. and Taylor, D.W. (2012), "Governance characteristics and role effectiveness of audit committees", Managerial Auditing Journal, Vol. 27 No. 4, pp.336-354.

Lawrence, A., Minutti-Meza, M. and Zhang, P. (2011), "Can Big" 4 versus Non-Big 4 differences in audit-quality proxies be attributed to client characteristics?, Accounting Review, Vol. 86, pp.259-286. 
Li, W.C.Y. and Hall, B.H. (2020), "Depreciation of business R\&D capital”, Review of Income and Wealth, Vol. 66 No. 1, pp.161-18o.

Lodhia, S. (2004), “Corporate environmental reporting media: A case for the World Wide Web”, Electronic Green Journal, Vol. 1 No. 20, pp.1-20.

Makiwane, T.S. and Padia, N. (2013), "Evaluation of corporate integrated reporting in South Africa post KingIII release South Africa: an exploratory enquiry”, Journal of Economic and Financial Sciences, Vol. 6 No. 2, pp.421-438.

Maroun, W. (2018), "Modifying assurance practices to meet the needs of integrated reporting: the case for “interpretive assurance”, Accounting, Auditing \& Accountability Journal, Vol. 21 No. 2, pp.40o-427.

Masulis, R. and Mobbs, S. 2013. "Independent director incentives: where do talented directors spend their limited time and energy?", Working paper, University of New South Wales and the University of Alabama.

Palenberg, M., Reinicke, W. and Witte, J.M. (2006), Trends in Non - Financial Reporting, Global Public Policy Institute, Berlin.

Picard, R. G. (2005), "Unique characteristics and business dynamics of media products”, Journal of Media Business Studies, Vol. 2 No. 2, pp.61-69.

Popova, T., Georgakopoulos, G., Sotiropoulos, I. and Vasileiou, K. (2013). "Mandatory Disclosure and Its Impact on the Firm Value”, International Business Research, Vol. 6 No. 5, pp.1-16.

Pratama, A. (2018a), "Does corporate governance affect related-party transactions? A study on Indonesian companies listed on the Indonesian Stock Exchange in 2011-2015", International Journal of Economic Policy in Emerging Economies, Vol. 11 No. 5, pp.470-478.

Pratama, A. (2018b), "How do Indonesian firms select their external auditors? Exploratory analysis of firm characteristics, corporate governance, and organisational complexity”, Review of Integrative Business and Economics Research, Vol. 7 No. 4, pp.63-76.

Pratama, A., Yadiati, W., Dewi Tanzil, N. and Suprijadi, J. (2019), “Designing an integrated reporting guidance: an initiative to improve environmental and social reporting quality / Diseño de una guía de informes integrados: una iniciativa para mejorar la calidad de los informes ambientales y sociales", Utopía y Praxis Latinoamericana, Vol. 24 No. 1, pp.218-238.

Prentice, R.A. (2012), “Good directors and bad behavior”, Business Horizons, Vol. 55 No. 6, pp.535-541.

Qian, Y. and Sayer, L.C. (2016), “Division of labor, gender ideology, and marital satisfaction in East Asia”, Journal of Marriage and Family, Vol. 78 No. 2, pp.383-40o.

Rivera-Arrubla, Y.A. and Zorio-Grima, A. (2016), "Integrated reporting, connectivity, and social media”, Psychology $\mathcal{E}$ Marketing, Vol. 33 No. 12, pp.1159-1165.

Roberts, R.W. (1992), "Determinants of corporate social responsibility disclosure: An application of stakeholder theory", Accounting, Organizations, and Society, Vol. 17 No. 6, pp.595-612.

Schwab, K. (2017), "The Fourth Industrial Revolution," World Economic Forum, available at: https://www.weforum.org/about/thefourthindustrialrevolutionbyklausschwab (accessed March 15, 2020).

Scott, W.R. (2009), Financial Accounting Theory, Pearson Prentice Hall, Toronto, Ont.

Setyonaluri, D. (2014), "Women interrupted: determinants of women's employment exit and return in Indonesia", Ph.D. diss. abstract, Bulletin of Indonesian Economic Studies, Vol. 50 No. 3, pp.485-486.

Siew, R.Y.J. (2015), “A review of corporate sustainability reporting tools (SRTs)”, Journal of Environmental Management, Vol. 164, pp.180-195.

Sobhani, F.A., Amran, A. and Zainuddin, Y. (2012), "Sustainability disclosure in annual reports and websites: a study of the banking industry in Bangladesh", Journal of Cleaner Production, Vol. 23 No. 1, pp.75-85.

Srinidhi, B., Gul, F.A. and Tsui, J. (2011), "Female' directors, and earnings quality", Contemporary Accounting Research, Vol. 28 No. 5, pp.1610-1644.

Stent, W. and Dowler, T. (2015), "Early assessments of the gap between integrated reporting and current corporate reporting”, Meditari Accountancy Research, Vol. 23 No. 1, pp.92-117.

Steyn, M. (2014), "Organisational benefits and implementation challenges of mandatory integrated reporting: perspectives of senior executives at South African listed companies", Sustainability Accounting, Management, and Policy Journal, Vol. 5 No. 4, pp.476-503.

Trang, V.T.T. and Phuong, N.C. (2015), "The disclosure in the annual reports by the listed firms on the Ho Chi Minh Stock Exchange”, International Journal of Business and Social Science, Vol. 6 No. 12, pp.117-126.

Uyar, A. (2016), "Evolution of corporate reporting and emerging trends", Journal of Corporate Accounting $\mathcal{E}$ Finance, Vol. 27 No. 4, pp.27-30.

Vafeas, N. (1999), Board meeting frequency and firm performance, Journal of Financial Economics, Vol. 53 No. 1, pp.113-142. 
Wang, M.C. (2017), "The relationship between firm characteristics and the disclosure of sustainability reporting, sustainability", Sustainability, Vol. 9 No. 624.

Yeo, G., Wai, L.K. and Thiruneeran (2014), "Integrated reporting and corporate valuation", available at: http://integratedreporting.org/wp-content/uploads/2014/o4/Integrated-Reporting-and-corporatevaluation-Media-28-April-2014_NTU.pdf (accessed 12 June 2017). 